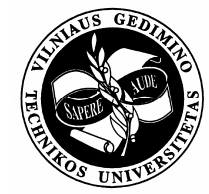

\title{
STRUCTURAL DESIGN OF POLYMER PROTECTIVE COATINGS FOR REINFORCED CONCRETE STRUCTURES. PART II: EXPERIMENTAL VERIFICATION
}

\author{
Zenonas Kamaitis \\ Dept of Bridges and Special Structures, Vilnius Gediminas Technical University, \\ Sauletekio al.11,LT-10223 Vilnius, Lithuania.E-mail: zenonas.kamaitis@ts.vtu.lt \\ Received 20 Feb, 2006; accepted 18 May 2006
}

\begin{abstract}
The ingress of various gases, liquids and ions from the environment is responsible for the deterioration of concrete structures. A large number and variety of protective surface treatments and coatings on the base of polymers have been developed for application to concrete surfaces in those instances, where special protection against aggressive attack is necessary. At the same time, new protective systems are continually appearing, whose adaptability to specific environments must in every case be proved. Semi-empirical predictive models for the deterioration over time are presented enabling design of coatings with required barrier properties. This paper describes the performance of a system based on inden-coumarone resins over a wide variety of exposures and application conditions and presents recommendations for design of such protective coatings.
\end{abstract}

Keywords: reinforced concrete, polymer coatings, physical/chemical resistance, diffusion, shrinkage and thermal stresses, reliability.

\section{Introduction}

Coatings may have a thickness ranging from approximately $100 \mu \mathrm{m}$ up to several milimeters. The task of thin film-forming surface sealers is to reduce the permeability of the surface to liquids/water, oxygen, carbon dioxide, chlorides and other aggressive man-made or atmospheric pollutants. The thick-bonded polymer mortar or polymer concrete overlays have to control the corrosion process and sometimes to provide fatigue, impact or abrasion resistance as well as structural strengthening effect.

Various types and formulations of polymer materials as coatings (epoxies, acrylics, polyesters, polyurethane, phenolics, vinyl ester and silicone resins, and others) for the specific application have been developed [eg 1-10] and majority of them are commercially available. Recently, the Carbon Fiber Reinforced Polymer (CFRP) wrapping is used as protective barrier [eg 11, 12]. But there is little information about its pre-corrosion effect. It should be noted that many coatings available for protection of concrete vary widely in their basic constituents and, therefore, in their uses. The variety of environmental actions and barrier materials results that the experience gained in one application is not transferable to other areas. Different polymers respond in different ways to the influence of aggressive chemical environments. At the same time, new protective systems are continually appearing, whose adaptability for specific environments must in every case be proved. A search of new compositions for coatings requires at the same time a semiempirical prediction of their properties to facilitate coating design. However, the theoretical justifications of various polymer protection systems for concrete structures are still in question and further research on their effectiveness is needed [13].

A number of investigations was carried out on the mechanical properties and durability of polymer-based materials, surface preparation for coatings and coating evaluation in laboratory or in-situ conditions. Although, there are only limited attempts to provide satisfactory analytical methods which can be used for design of polymer coatings. Mechanisms of degradation, limit state definition and principles of designing polymer coatings are presented [14].

The objective of this paper was to summarise the results of the author's experience on investigation, theoretical prediction of properties and application of polymer resin coatings IKAS used for protecting RC structures in liquid aggressive environments with the aim to illustrate the use of design procedures outlined in the author's preceding paper [14].

\section{Prognosis of polymer coatings protective properties}

The damaging process in polymer coatings is governed mainly by permeability/diffusion and chemical/physical degradation due to the losses in intermolecular cohesion and interaggregate adhesion leading to breakdown of its chemical structure, which can be viewed as a degradation of the mechanical properties and thickness losses [14]. Coating thickness changes in a particular aggressive environment or a depth of degradation $x(t)$ is a function of the initial coating thickness $d_{p c}$ and the time $t$ : 


$$
x(t)=f\left(d_{p c} ; t\right) .
$$

Assuming that the degree of degradation of mechanical properties (or penetration) varies with time the changes of coating thickness $d_{p c}(t)$ can be obtained as follows:

$$
d_{p c}(t)=d_{p c} \varphi_{d}(t)
$$

Different polymers respond in different ways to the influence of aggressive environments. The time-dependent monotone decreasing degradation function $\varphi_{d}(t)$ can be expressed in different forms (linear, parabolic, square root etc) with the following boundary conditions:

$$
\begin{aligned}
& \text { at } t=t_{0}, \varphi_{d}\left(t_{0}\right)=1,0, \\
& \text { at } t=t_{d}, \varphi_{d}\left(t_{d}\right)=\varphi_{\min },
\end{aligned}
$$

where $t_{d}$ is target or design time of coating.

Mechanical damage of coatings is here modelled by introducing a simple exponential degradation model in the form of

$$
\varphi_{d}(t)=\exp (-\lambda t)
$$

or

$$
d_{p c}(t)=d_{p c} \exp (-\lambda t)
$$

where $d_{p c}$ is initial coating thickness at $t=0 ; \lambda$ is the rate of degradation.

From $\mathrm{Eq}(4)$ the required initial coating thickness is:

$$
d_{p c}=d_{p c}(t) \exp (\lambda t)
$$

From Eq (5) the service time of coating is expressed as

$$
t_{p c}=\frac{1}{\lambda} \ln \frac{d_{p c}}{d_{\min }},
$$

where $d_{\min }$ is minimum acceptable coating thickness indicating an allowable extent of coating degradation to be unserviceable.

If $t_{p c}<t_{d}$, where $t_{d}$ is design time of protective barrier, the periodic recoating is required. In general, the rate of degradation $\lambda$ is difficult to determine. In this study, the values of $\lambda$ were determined from regression analysis of the experimental results.

The limit state of damage of polymer coating may be represented as follows:

$$
\begin{gathered}
g(t)=d_{p c}(t)-d_{\min } \geq 0, \\
g(t)=n t_{p c}-t_{d} \geq 0,
\end{gathered}
$$

where $n$ is number of recoating.

Due to randomness of coating deterioration and its time-variant nature, it is justifiable to model coating deterioration as stochastic process. The survivor function of protective coating can be expressed as follows:

$$
P\left\{t_{p c}\right\}=P\left\{d_{p c}(t) \geq d_{\min }\right\} \geq \Phi\left(\beta_{T}\right) \text { for } 0<t \leq t_{d}
$$

or in life time format

$$
P\left\{t_{p c}\right\}=P\left\{n t_{p c}-t_{d} \geq 0\right\} \geq \Phi\left(\beta_{T}\right) \text { for } 0<t \leq t_{d} .
$$

If $d_{p c}$ and $x(t)$ [or $d_{p c}(t)$ ] are treated as a normal random variables, then

$$
\begin{aligned}
& P\left\{t_{p c}\right\}=P\left\{d_{p c} \geq x(t)\right\}=\Phi(\beta)= \\
& \Phi\left\{\frac{\mu_{\theta d} \mu_{d}-\mu_{\theta x} \mu_{x}}{\left(\sigma_{d}^{2}+\sigma_{x}^{2}\right)^{1 / 2}}\right\} \geq P_{t \text { arg }},
\end{aligned}
$$

where $\mu_{\bullet}$ and $\sigma_{\bullet}$ are the mean and standard deviation of $\bullet$; $P_{\text {targ }}$ is a target reliability.

\section{Experimental investigation of polymer coatings}

\subsection{Coating materials}

Research involving the evaluation of various synthetic resin systems has been conducted to establish essential performance criteria required for design of protective coatings and its field of applications. The protective coating systems tested included commercially available epoxy, polyester and copolymers of indenecoumarone-acrylate (IKAS) to determine effects of formula variations on the mechanical properties and physical/chemical resistance. The viscosity, pot life, thickness of coating, physical/chemical resistance, and cost vary with the grade of filler or aggregate used in the formulation. Three types of coatings, based on resin content were investigated: mastics, mortars or polymer concrete corresponding to high-, medium- or low-resin content. The polymer compounds were composed of polymer resins, hardeners or accelerators containing various types (cement, silica, andesit, diabase) and quantities of mineral filler (ratio of binder to filler from 1:0 to 1:5 by weight) or filler and mineral aggregate (from 1:6 to 1:14). An analysis of the strength test results obtained indicated that fillers, desirable for compound economy, improve abrasion and impact resistance and minimise shrinkage during curing as well as coefficient of thermal expansion closely approximated that of concrete.

Epoxy and polyester resin systems have been widely investigated and have the longest history of satisfactory use and is not presented here due to limited space of the paper. Less well-known are low-cost IKAS resins. The main emphasis was on the physical/chemical resistance of polymer compositions and application of design procedures of coatings to use them for anticorrosion works.

The coating systems IKAS have the properties given in Table 1.

Table 1. Properties of IKAS systems

Unfilled compounds

\begin{tabular}{ll}
\hline Viscosity, cps at $+20{ }^{\circ} \mathrm{C}$ & $600-900$ \\
Density, g/cm & $1,02-1,12$ \\
Gel time, min & $120-180$ \\
Peak exothermal temperature, ${ }^{\circ} \mathrm{C}$ & $150-170$ \\
Shrinkage, $\%$ & $2,0-2,5$ \\
\hline Filled coatings (mastics, polymer concrete) & \\
\hline Tensile strength, MPa & $9-10$ \\
Compressive strength, MPa & $80-90$ \\
Flexural strength, MPa & $18-22$ \\
Flexural modulus, MPa & $(0,2-0,6) \times 10^{4}$ \\
Coefficient of linear extension & $(3-4) \times 10^{-5}$ \\
\hline
\end{tabular}




\subsection{Assessing service life and performance}

The durability models were applied to the experimental results of the author's research program, which has been reported previously [2]. In this reference tests program and procedures are reported in detail and are not presented here due to limited space of paper.

Two basic mechanism of deterioration of coatings IKAS in liquid chemical solutions were used to analyse the performance of polymer coatings, including mechanical degradation and calculating diffusion through the polymer coating.

\subsubsection{Chemical/physical resistance}

The performance of polymer coatings can be predicted using Eqs (5) and (6) by assuming that the degradation function (ratio of the polymer composite strength at time $t, f_{p}(t)$, to initial strength at $\left.t=0, f_{p 0}\right)$, of polymer can be expressed by the following exponential function:

$$
\varphi_{R}(t)=\varphi_{R}(t)=\frac{f_{p}(t)}{f_{p 0}}=\exp (-\lambda t),
$$

where $\lambda$ is the degradation rate, which is assumed as constant for a given material and exposure environment and is obtained experimentally according to following procedure.

Taking natural logarithms of both sides of Eq (12) for time $t_{i}$, we get $\ln \varphi_{R i}=-\lambda t_{i}$ Having for the set of times $t_{i}$ the values of $\varphi_{R i}$ and using the minimum sum of square errors procedure $\Sigma n_{i}\left(\lambda t_{i}+\ln \varphi_{R i}\right)^{2}=$ min we obtain

$$
\lambda=-\frac{\sum n_{i} t_{i} \ln \varphi_{R i}}{\sum n_{i} t_{i}^{2}},
$$

where $n_{i}$ is the number of specimens tested at time $t_{i}$.

As an example, Table 2 contains some values of $\lambda$ calculated using Eq (13). The performance of polymer coatings then can be calculated using Eqs (5) and (6).
When $d_{\min }$ is set equal, for example, to $0,1 \mathrm{~mm}$, the required thicknesses of protective coatings for different life cycles are summarised in Table 2 . When initial coating thickness, $d_{p c}$, is known, the time between recoating is obtained from Eq (6). If required, coating thickness of mastics exceeds approx $5 \mathrm{~mm}$, the thicker mortar or polymer concrete coatings should be designed.

Aggressive actions as well as material and geometric properties of coatings may vary substantially. Therefore, the durability of coatings has to be evaluated by reliability-based analysis.

The life time prediction of coatings can be formulated in a probabilistic form as follows:

$$
P\left\{\frac{\mu_{d}(t)-\mu_{d \cdot \min }}{\left[\mu_{d}^{2}(t) V_{d}^{2}+\sigma_{d \cdot \min }^{2}\right]^{1 / 2}}\right\} \geq P_{t \text { arg }} .
$$

If $d_{\min }=$ const, then

$$
P\left\{\frac{\mu_{d}(t)-d_{\min }}{\mu_{d}(t) V_{d}}\right\} \geq P_{t \text { arg }} .
$$

The mean function of coating deterioration $\mu_{d}(t)$ is in the form of

$$
\mu_{d}(t)=\mu_{d} \exp (-\lambda t)
$$

where $\mu_{d}$ is mean value of initial coating thickness at $t=0 ; V_{d}$ is coefficient of variation of coating thickness.

The relationships between reliability and time for different aggressive exposures are presented in Fig 1. The service life of coatings is defined as the time when the reliability of the particular coating falls below an acceptable level. The level of acceptable reliability can be established based on performance requirements or economic considerations. For example, an acceptable probability of coating degradation of 0,1 may be specified, representing a reliability of 0,9 . As can be seen fro Fig 1,

\begin{tabular}{|c|c|c|c|c|c|c|c|}
\hline \multirow[t]{2}{*}{ Type of chemical solution } & \multirow[t]{2}{*}{$\begin{array}{l}\lambda, 1 / \text { year, see } \\
\text { Eq. (13) }\end{array}$} & \multicolumn{3}{|c|}{$\begin{array}{c}\text { Required } d_{p c}(\mathrm{~mm}) \text { after } t \text { years, see } \\
\mathrm{Eq}(5)\end{array}$} & \multicolumn{3}{|c|}{$\begin{array}{c}\text { Service life } t_{p c} \text { (years) with } d_{p c}(\mathrm{~mm}) \text {, see } \\
\mathrm{Eq}(6)\end{array}$} \\
\hline & & 5 & 10 & 20 & 1 & 2 & 5 \\
\hline Water, $\sim+20^{\circ} \mathrm{C}$ & 0,184 & 0,250 & 0,630 & 3,960 & 12,5 & 16,3 & 21,3 \\
\hline $\mathrm{H}_{2} \mathrm{SO}_{4}, 10 \%$ & 0,138 & 0,190 & 0,397 & 1,580 & 16,7 & 21,7 & 28,3 \\
\hline $\mathrm{H}_{2} \mathrm{SO}_{4}, 30 \%$ & 0,131 & 0,192 & 0,371 & 1,370 & 17,6 & 22,9 & 29,8 \\
\hline $\mathrm{NaOH}, 10 \%$ & 0,089 & 0,156 & 0,243 & 0,593 & 25,8 & 33,7 & 43,9 \\
\hline $\mathrm{NaCl}, \sim+20{ }^{\circ} \mathrm{C}$ & 0,043 & 0,124 & 0,154 & 0,236 & 53,5 & 69,8 & 90,9 \\
\hline $\mathrm{NaCl}, \sim+40{ }^{\circ} \mathrm{C}$ & 0,095 & 0,160 & 0,259 & 0,668 & 24,2 & 31,6 & 41,2 \\
\hline Petrol & 0,092 & 0,158 & 0,250 & 0,630 & 25,0 & 32,6 & 42,5 \\
\hline Hypochlorite & 0,073 & 0,140 & 0,210 & 0,430 & 31,5 & 41,1 & 53,6 \\
\hline Caustic soda, $33 \%$ & 0,081 & 0,150 & 0,225 & 0,505 & 28,4 & 37,0 & 48,3 \\
\hline $\mathrm{Na}_{2} \mathrm{SO}_{3}, 2 \%$ & 0,099 & 0,164 & 0,269 & 0,724 & 23,2 & 30,3 & 39,5 \\
\hline Acetic acid, $5 \%$ & 0,701 & 3,330 & $>5$ & - & 3,30 & 4,30 & 5,60 \\
\hline Weakly organic acidic solution & 1,028 & $>5$ & - & - & 2,20 & 2,90 & 3,80 \\
\hline
\end{tabular}
the coatings have a water transmission rate clearly higher than the other substrates tested. Their resistance to acids and alkalies is moderate and very good in salts.

Table 2. Coatings durability computed according to Eqs (5), (6) and (13) 
a)

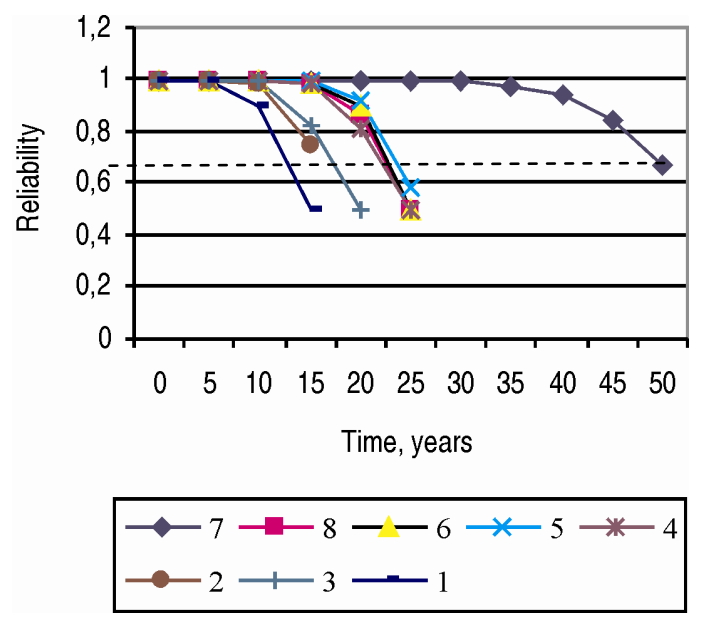

b)

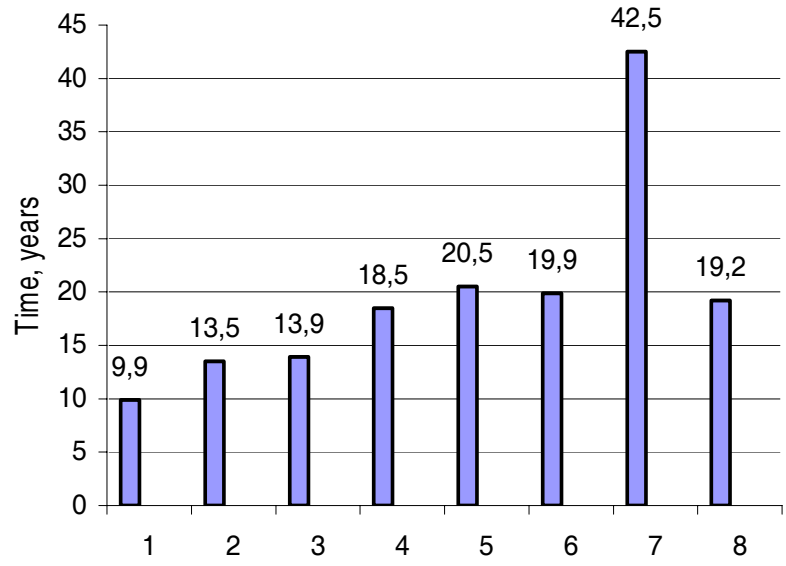

Fig 1. Probability of serviceability (a) and service life (b) of polymer coatings in different exposure conditions: $1-\mathrm{H}_{2} \mathrm{O} ; 2-\mathrm{H}_{2} \mathrm{SO}_{4} 10 \% ; 3-\mathrm{H}_{2} \mathrm{SO}_{4} 30 \% ; 4-\mathrm{Na}_{2} \mathrm{SO}_{3}$ $2 \% ; 5-\mathrm{NaOH} 10 \% ; 6-$ Petrol; $7-\mathrm{NaCl}+20{ }^{\circ} \mathrm{C}$; $8-\mathrm{NaCl}+40{ }^{\circ} \mathrm{C} ; d_{p c}=1 \mathrm{~mm}, d_{\min }=0,1 \mathrm{~mm} ; V_{d}=V_{d \min }=$ 0,25

Table 3. Typical coating parameters

\begin{tabular}{|c|c|c|c|c|}
\hline Variables & Distribution & $\begin{array}{c}\text { Mean } \\
m_{d}\end{array}$ & Cov & $\begin{array}{c}s_{d} \\
\mathrm{~mm}\end{array}$ \\
\hline \multirow{5}{*}{$\begin{array}{l}\text { Initial coating } \\
\text { thickness, } d_{p c}\end{array}$} & \multirow[t]{6}{*}{ Normal } & \multirow{2}{*}{$1 \mathrm{~mm}$} & 0,15 & 0,15 \\
\hline & & & 0,25 & 0,25 \\
\hline & & \multirow[t]{2}{*}{$2 \mathrm{~mm}$} & 0,15 & 0,30 \\
\hline & & & 0,25 & 0,50 \\
\hline & & $5 \mathrm{~mm}$ & 0,15 & 0,75 \\
\hline \multirow{4}{*}{$\begin{array}{l}\text { Admissible } \\
\text { coating thick- } \\
\text { ness, } d_{\min }\end{array}$} & & & 0,25 & 1,25 \\
\hline & \multirow[t]{3}{*}{ Normal } & $0,05 \mathrm{~mm}$ & 0,25 & 0,0125 \\
\hline & & $0,10 \mathrm{~mm}$ & 0,25 & 0,0250 \\
\hline & & $0,15 \mathrm{~mm}$ & 0,25 & 0,0375 \\
\hline $\begin{array}{c}\text { Rate of degra- } \\
\text { dation }\end{array}$ & Constant & $\lambda 1 /$ year & 0 & 0 \\
\hline
\end{tabular}

The parametric sensitivity analysis of predictive techniques may be demonstrated by evaluating the reliability of the coatings over various times for differing design parameters. For example, consider the parameters shown in Table 3. Coefficient of variation was determined experimentally. The experimental measurements of coating thickness suggest that $V_{d}$ is in the range of $0,15-0,25$.

Some results of computed life times of coatings are presented in Figs 2-4. As can be seen, life times of coatings are closely related to exposure conditions, initial and admissible coating thicknesses.

a)
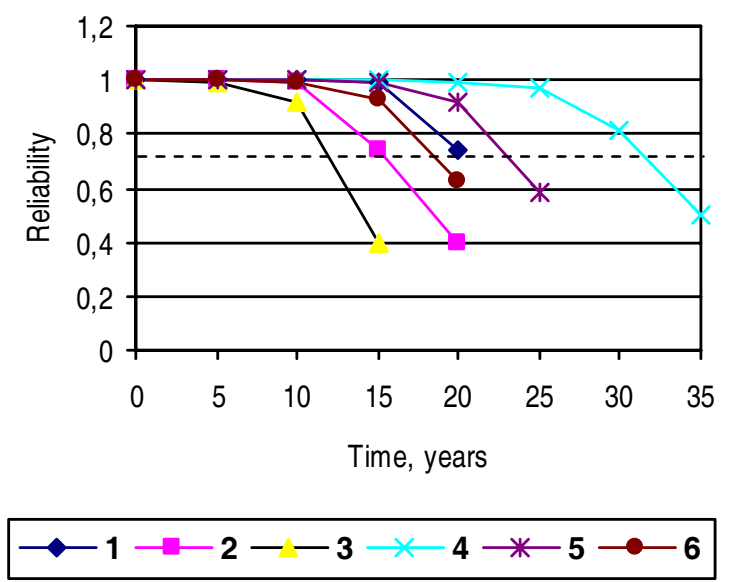

b)

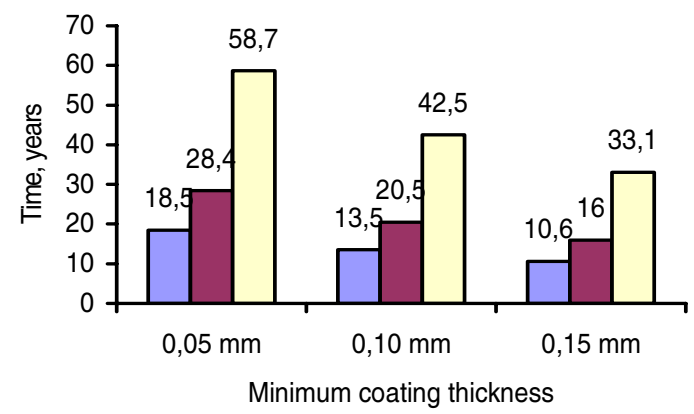

$\square \mathrm{a} \square \mathrm{bc}$

Fig 2. Effect of $d_{\min }$ on the reliability (a) and service life (b) of polymer coatings of $d_{0}=1 \mathrm{~mm}, V_{d}=V_{d \cdot \min }=0,25$ : $1\left(\mathrm{H}_{2} \mathrm{SO}_{4}, 10 \%\right)$ and $4(\mathrm{NaOH} 10 \%)-d_{\min }=0,05 \mathrm{~mm}$; $2\left(\mathrm{H}_{2} \mathrm{SO}_{4}, 10 \%\right)$ and $5(\mathrm{NaOH} 10 \%)-d_{\min }=0,1 \mathrm{~mm}$; $3\left(\mathrm{H}_{2} \mathrm{SO}_{4}, 10 \%\right)$ and $6(\mathrm{NaOH} 10 \%)-d_{\min }=0,15 \mathrm{~mm}$ $\left(\mathrm{H}_{2} \mathrm{SO}_{4}, 10 \%\right) ; \mathrm{a}-\mathrm{H}_{2} \mathrm{SO}_{4} 10 \%$; b - NaOH, $10 \%$; c $\mathrm{NaCl}$

The results of analysis in Fig 2 indicate the reduction up to approx $40 \%$ in service life as the allowable minimum coating thickness is increased from 0,05 to $0,15 \mathrm{~mm}$. As the initial average coating thickness is increased from 1 to $5 \mathrm{~mm}$, the service life increases no more than approx 2 times (Fig 3). The expected service life decreases slightly with the increase in COV of the initial coating thickness from 0,15 to 0,25 (Fig 4). 
a)
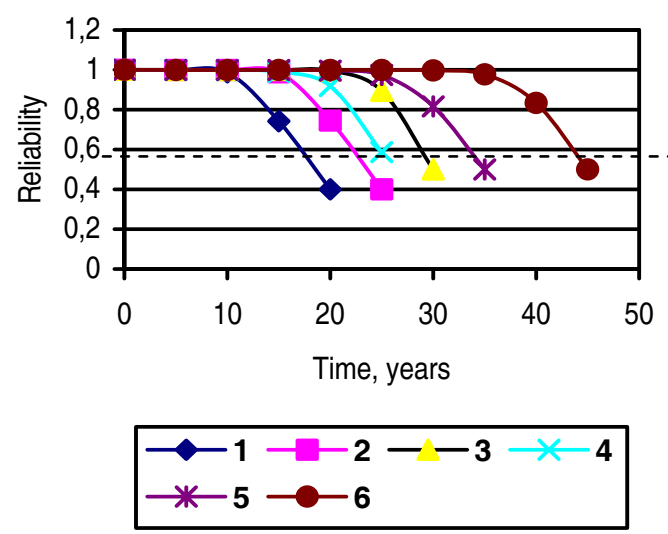

b)

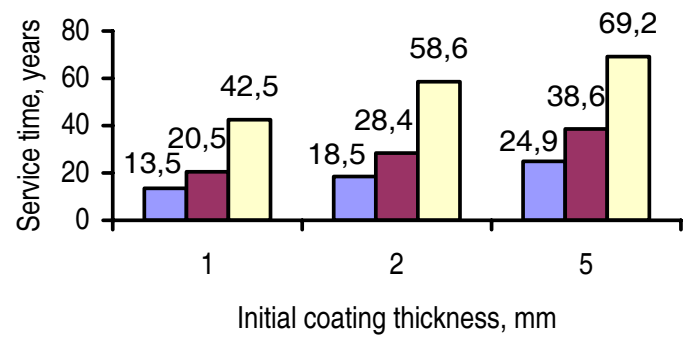

$\square a \mathbf{a b} \square$

Fig 3. Effect of coating thickness $d_{p c}(1$ and $4-1 \mathrm{~mm}$; 2 and $5-2 \mathrm{~mm} ; 3$ and $6-5 \mathrm{~mm}$ ) on the reliability (a) and service life (b) of polymer coatings in $\mathrm{H}_{2} \mathrm{SO}_{4}, 10 \%(1,2$, 3 ) and $\mathrm{NaOH}, 10 \%(4,5,6) 10 \%$ solutions; $\mathrm{a}-\mathrm{H}_{2} \mathrm{SO}_{4}$, $10 \% ; \mathrm{b}-\mathrm{NaOH}, 10 \% ; \mathrm{c}-\mathrm{NaCl}$
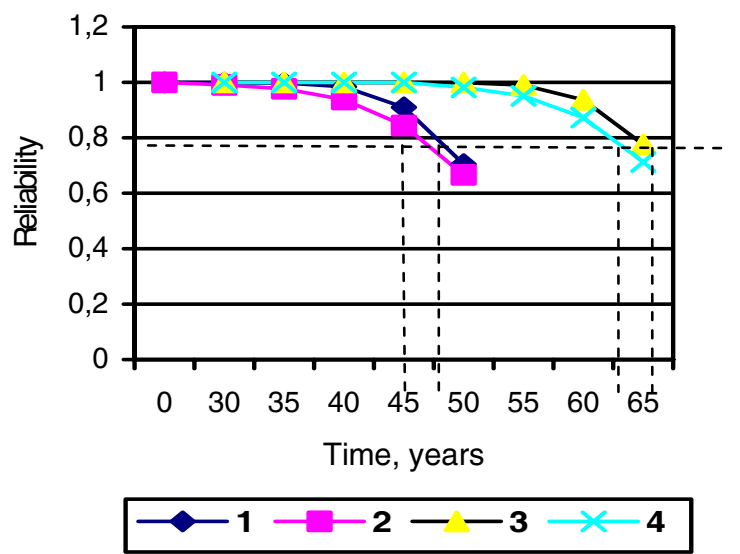

Fig 4. Probability of serviceability of polymer coatings of $d_{p c .0}=1 \mathrm{~mm}$ in $\mathrm{NaCl}$ solutions: $1-d_{\min }=0,10, V_{d}=0,15$; $2-d_{\min }=0,10, V_{d}=0,25 ; 3-d_{\min }=0,05, V_{d}=0,15$; $4-d_{\min }=0,05, V_{d}=0,25$

\subsubsection{Diffusion process}

As was shown in [14], the performance of polymer coatings can be modelled based on Fick's diffusion law as follows

$$
c(x ; t)=c_{0}\left(1-\operatorname{erf} \frac{x}{2 \sqrt{D t}}\right),
$$

where $c(x ; t)$ and $c_{0}$ are concentration of aggressive agents at depth $x$ after time $t$ and on surface, respectively; $D-$ apparent diffusion coefficient of coating; erf - the standard error function.

When $c(x ; t)$ is set equal to the aggressiveness threshold level $c_{c r}$, Eq (17) is solved for $x=d_{p c}$. When $x=d_{p c}$ and $c_{x}=c_{c r}$, Eq (17) is solved for $t=t_{p c}$.

The time $t_{p c}$ is highly sensitive to diffusion coefficient and $c_{x}$ values. For low values of $D$ and relationship $c_{x} / c_{0}$ approaching one, a very large time is required for the aggressive agents to diffuse through the coating reaching the concrete surface or threshold level $c_{c r}$. For high values of $D$ and $c_{x} / c_{0}$ values that are much less than 1,0 the predicted time to be shorter. The values for the parameters $c_{x} / c_{0}$ and $D$ are not presently known with certainty. The exact concentration of aggressive agents on the concrete surface, $c_{c r}$, to initiate deterioration of coating depends on several factors. $D$ may be constant or a function of different variables, such as time, temperature, concentration, location etc. Frequently for simplicity it is assumed that $D$ is independent of time.

In order to cause the loss of protection ability of thin coating due to diffusion process, aggressive agents must penetrate the coating $\left(t_{c}\right)$ and destroy the adhesion between coating-substrate $\left(t_{a d h}\right)$, leading to delamination and cracking of coating $\left(t_{c r}\right), \mathrm{i} \mathrm{e}$, when degradation signs are visible. Thus, the lifetime of the coating is defined as [14]:

$$
t_{p c}=t_{c}+t_{a d h}+t_{c r} .
$$

As can be seen from Eq (18) different definitions of uncerviceability of coating can divide $t_{p c}$ in three life cycles. For example, in this paper it was assumed that the coating limit state develops when corrosion agents reach the concrete surface, ie $t_{p c}=t_{c}$ or $c_{x} / c_{0}=0$ in Eq (17). The diffusion coefficient was determined experimentally. The values of $D$ between $0,09 \times 10^{-6}$ and $0,656 \times 10^{-6} \mathrm{~mm}^{2} / \mathrm{s}$ were obtained for exposure conditions presented in $\mathrm{Ta}$ ble 2 . The $D$ coefficients obtained were very similar to the diffusion coefficients of other polymer coating systems recorded in other works. According to Eq (18), predicted time $t_{p c}$ to the first repair of coatings of $d_{p c}=5 \mathrm{~mm}$ are in the range only of 1 year that is deemed to be unrealistic and very conservative for assessing the coating life time. Coatings in various exposure conditions observed in industry structures performed better than the design procedure assumes. It seems that design shows a considerable degree of conservatism since they showed no evidence of failure after exposure of 5-10 years.

$\mathrm{Eq}(17)$ can be solved for ratio $c_{x} / c_{0}$ using experimental values of $D$ and assuming that $t=t_{p c}$ from Eq (6) (see Table 2). The mean value of $c_{x} / c_{0}$ obtained was 0,789 with the coefficient of variation of $2,3 \%$.

The time periods $t_{a d h}$ and $t_{c r}$ for destroying adhesion and delamination of coating until acceptable level [that can be expressed by the relationship $c_{c r} / c_{0}$ in Eq (17)] are attributed to many factors and in every specific case need to be determined. 
From the present analysis it is evident that the values for the parameters in Eqs (17) and (18) are not known with certainty and the design of coatings on the basis of diffusion process is a very complex phenomenon.

\subsubsection{Shrinkage and thermal stresses}

Polymer coatings have to resist cracking and rebounding due to curing contraction stresses and thermal stresses under service conditions.

The shrinkage (internal) stresses were determined experimentally (Fig 5). They vary parabolically from zero at $t=t_{0}$ to a maximum at $t=t_{c r}(\approx 24 \mathrm{~h})$. Through the mechanism of relaxation, the peak stress in the polymer mastic will tend to be reduced. The remaining stress is then approximately one-third of the maximum.

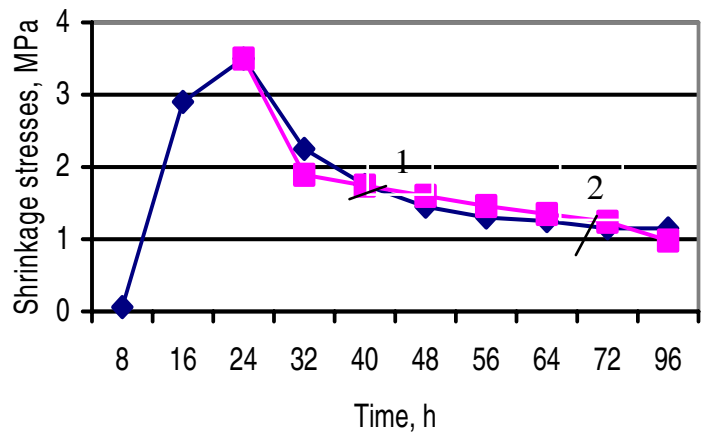

Fig 5. Comparison between experimental shrinkage stresses (1) and the computed values (2) based on Eq (21) of polymer mastic $(1: 2,25)$

Table 4 shows the ratio of the maximum shrinkage stress $\left(\sigma_{s h \text { max }}\right)$ to the ultimate tensile strength $\left(f_{p t}\right)$ at $t=24 \mathrm{~h}$ of various polymer mixes. This relation is chosen to illustrate the relative possibility of shrinkage cracking of the different mixes. The shrinkage cracking probability of polymer coatings IKAS, evaluated using the reliabilitybased assessment, is presented in Table 4. It can be seen that shrinkage cracking probability is very low. This is proved during the visual inspections of industry building floors on large areas, chemical storage tanks, and industrial chimneys, where no visual evidence of distress of mastic coatings after its application and curing was recorded.

The weathering tests, involving freeze-thaw and heating, show that a softening action occurred of coatings resulting in increased elongation and decreased modulus of elasticity and tensile strength (Fig 6).

As was shown in [14], the shrinkage and thermal stresses can be found using hyperbolic functions or stress intensity factor, $K_{I}$. For practical purposes more simple well-known expressions can be used.
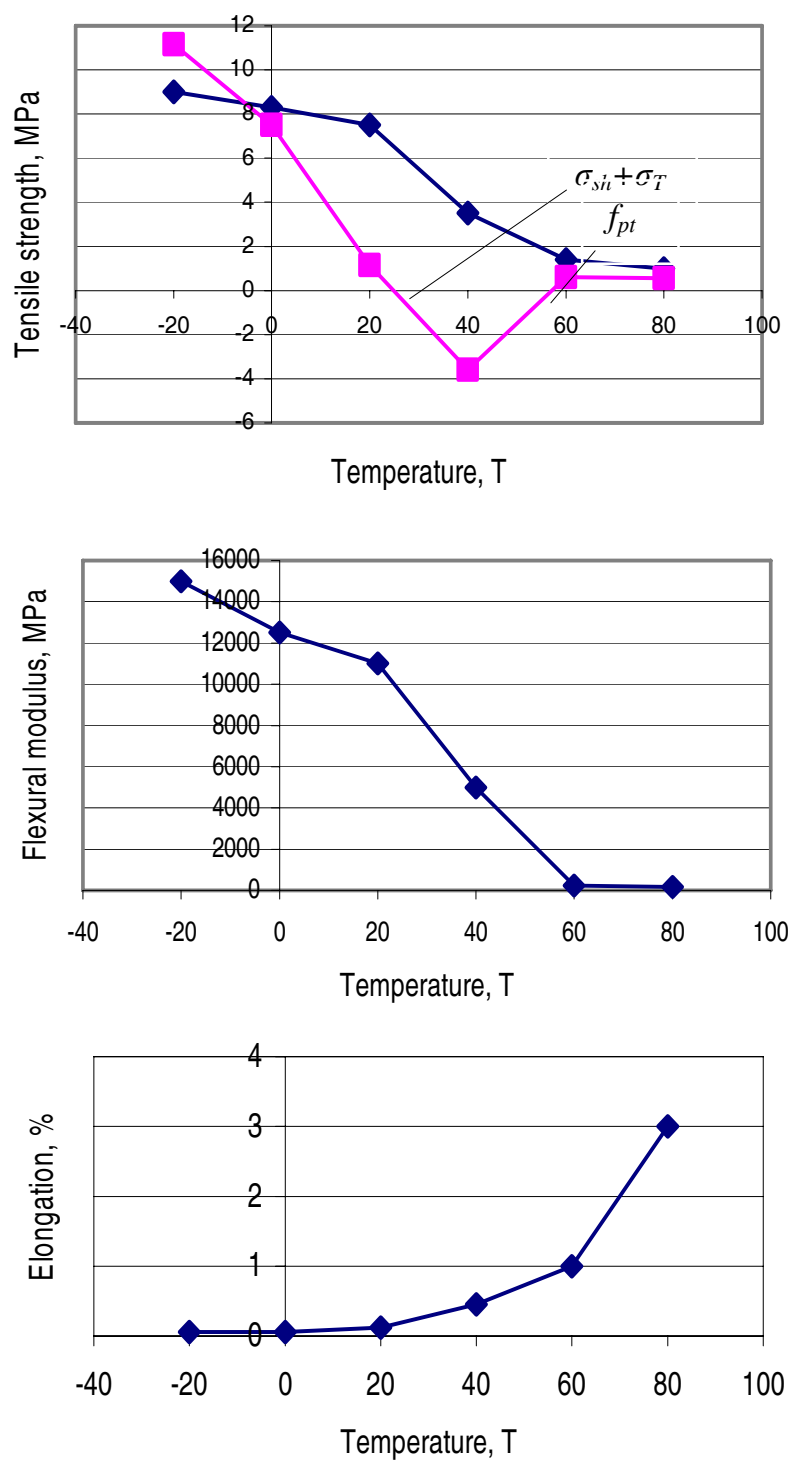

Fig 6. Effect of temperature on mechanical properties of polymer mastic $(1: 2,25)$ follows:

Shrinkage stresses in coating can be computed as

$$
\sigma_{s h \text { max }}=0,3 \frac{\varepsilon_{s h} E_{p c}}{1-\mu}
$$

Table 4. Maximum shrinkage stresses for various polymer mixes

\begin{tabular}{c|c|c|c|c|c|c|c}
\hline \multirow{2}{*}{ Mixes } & \multicolumn{2}{|c|}{$\sigma_{\text {sh.max }}, \mathrm{MPa}$} & \multicolumn{2}{|c|}{$f_{p t}, \mathrm{MPa}$} & \multirow{2}{*}{$m_{f} / m_{\sigma}$} & \multirow{2}{*}{ Cracking probability, $P_{f}$} & ${ }^{1}$ mastic \\
& $m_{\sigma}$ & $s_{\sigma}$ & $m_{f}$ & $s_{f}$ & & & \\
& \cline { 2 - 6 } resin mortar & \\
& $1: 0^{1}$ & 0,42 & 4,5 & 0,540 & 1,86 & $7,40 \times 10^{-4}$ & \\
$1: 1^{1}$ & 2,90 & 0,410 & 5,9 & 0,679 & 2,03 & $0,78 \times 10^{-4}$ & \\
$1: 2,25^{1}$ & 3,50 & 0,343 & 7,5 & 0,780 & 2,14 & $0,013 \times 10^{-4}$ & \\
$1: 5,87^{2}$ & 2,35 & 0,122 & 3,9 & 0,351 & 1,66 & $0,15 \times 10^{-4}$ & \\
$1: 8,20^{3}$ & 1,97 & 0,320 & 3,5 & 0,281 & 1,77 & $1,59 \times 10^{-4}$ & \\
$1: 14,35^{3}$ & 1,10 & 0,085 & 2,5 & 0,275 & 2,27 & 0 & \\
\hline
\end{tabular}


and thermal stresses as

$$
\sigma_{T}=\frac{E_{p c}\left(\alpha_{p c}-\alpha_{c o n}\right) \Delta T}{1-\mu},
$$

where $\varepsilon_{s h}, E_{p c}$ and $\mu$ are shrinkage strain, modulus of elasticity and Poisson's ratio of the coating, respectively; $\alpha_{c o n}$ and $\alpha_{p c}$ are coefficient of thermal expansion of the substrate and coating layer, respectively.

From the solution of $\mathrm{Eq}$ (19) for $\varepsilon_{s h}=0,0065, E_{p}=$ $1154 \mathrm{MPa}$ and $\mu \approx 0,4$ at $t=24 \mathrm{~h}$ the value of $3,75 \mathrm{MPa}$ is obtained for $\sigma_{s h \text { max }}$. The agreement between the calculated $(3,75 \mathrm{MPa})$ and test $(3,50 \mathrm{MPa}$, see Table 4) results is fairly good.

The remaining shrinkage stresses at time $t$ in the coating are obtained as follows [14]:

$$
\sigma_{s h}(t)=\sigma_{\text {sh.max }} K_{t . r e l} \text {. }
$$

Coefficient of relaxation is given by the following equation:

$$
K_{\text {t.rel }}=\beta_{t} \exp \left(-\frac{t-t_{c r}}{t_{r e l}}\right)
$$

where $\beta_{t}$ is a non-dimentional constant for a given material; $t_{\text {rel }}$ is a relaxation time.

From test data $\beta_{t}=0,586 ; t_{c r}=24 \mathrm{~h} ; t_{r e l}=96 \mathrm{~h}$. Comparison between test results and values predicted by $\mathrm{Eq}$ (22) indicate a close agreement as represented by Fig 5.

The temperature stresses can be established with similar expression:

$$
\sigma_{T}(t)=\sigma_{T} K_{T . r e l}
$$

with coefficient of relaxation

$$
K_{\text {T.rel }}=\exp \left(-\frac{T-T_{c r}}{\beta_{T}}\right),
$$

where $\beta_{T}$ is a constant for a given material.

$$
\begin{aligned}
& \text { If } T_{0}>T_{c}, T_{c r}=T_{0} ; \\
& \text { if } T_{0}<T_{c} T_{c r}=T_{c} .
\end{aligned}
$$

$T_{0}$ is the temperature below which only elastic strains occur; $T_{c}$ is the initial temperature at the time of coating completion.

The rate of curing of polymer materials varies considerably with temperature and may be inhibited at temperatures below $+10{ }^{\circ} \mathrm{C}$. Normally the temperatures of application of coating, $T_{c}$, between $+10{ }^{\circ} \mathrm{C}$ and $+25^{\circ} \mathrm{C}$ are recommended. In the analysis discussed here it was assumed that after curing of coating a temperature is suddenly applied and remains constant during operation.

Temperature stresses should always be considered in addition to those resulting from shrinkage. Fig 6 shows the comparison of the maximum residual stresses $\left(\sigma_{s h}+\sigma_{T}\right)$ to the ultimate tensile strength $\left(f_{p t}\right)$ of polymer coating. It is assumed that Poisson's ratio remains constant during temperature changes. This, if only approximately true, will in general simplify the stress analysis. After application and curing of coating $\left(T_{c} \approx+18-20^{\circ} \mathrm{C}\right)$ the total stresses due to shrinkage and positive temperature changes will be reduced due to the reduced elastic modulus and relaxation process. The tensile elastic stresses $\left(K_{\text {T.rel }}=1\right)$ in negative temperature areas may be of the magnitude sufficient to cause coating cracking and to destroy the bond between coating and concrete. Seeking to use polymer materials IKAS as a protective treatment on actual highway bridge structures, to improve its resistance to salt scaling of concrete has been not successful. It is recognised, however, that these materials can show delamination under severe cyclic climatic conditions.

\section{Application}

The low viscosity IKAS compounds (mastics and mortars) resist attack and penetration of water, variety of chemicals, salts, petrol, caustics. They have excellent adhesion to concrete, abrasion and weathering resistance. Coatings have a water transmission rate clearly higher than the other substrates tested. They are not resistant to organic solvents, acetic acid and have limited resistance to heat. Coatings tend to yellow on exposure to sunlight, but this yellowing does not seem to affect the protective properties of the coatings. In general, IKAS coatings have good durability, although not as good as epoxy coatings, but the later are more expensive.

The barrier protection may be needed for preventing the chemical/physical attack on concrete in such places as industrial floors, chemical storage tanks, industrial chimneys, and bridge structures. Some experimental mastic, resin mortar and resin concrete surfacing were designed for specific applications as water-treatment works, reservoirs, sewage works, self-levelling industrial floors and ground for storage of salts. Thickness varies from $2 \mathrm{~mm}$ for light-duty use to $5 \mathrm{~mm}$ for heavy-duty use.

Detailed information about the properties of polymer compositions IKAS and the field of their application is given in the book [2].

\section{Conclusions}

This paper has demonstrated that proposed deterioration mechanism and limit state functions can be efficiently applied to assess the service life and performance of protective polymer coatings under different liquid exposure conditions. Polymer coatings IKAS protect concrete against a variety of chemicals which are mildly aggressive. Based on the experimental results from previous investigations, the models (5), (6), (7) and (8) were proposed to calculate the design parameters of polymer coatings. Once the parameter of deterioration, $\lambda$, is predetermined for various polymer coatings and exposure conditions, this approach results in a simple and reliable method for determining coating performance. The design of coating parameters based on diffusion process [see Eq (17)] is highly sensitive to diffusion coefficient and $c_{x} / c_{0}$ values which are not well defined. By using reliability as a measure of performance [see Eqs (14), (15) and (16)], decisions concerning material selection, thickness of coating, maintenance schedules, repair and rehabilitation of polymer coatings can be made throughout the lifecycle of protective structures.

One important requirement for polymer coatings is maintaining cracking resistance and adhesion to concrete surface during formation of coating or temperature 
changes in service. Large stresses can develop as a result of expansion mismatches between constituent materials. The prediction of shrinkage [Eq (19)] and temperature [Eq (20)] stresses taking into account relaxation process [Eqs (22) and (24)] is developed. The predictions and experimental data are in good agreement.

The predictive techniques, described within this paper, have been successfully applied for the prediction of service life of coatings in chemical storage tanks in the factories of light industry.

\section{References}

1. ANGELMAYER, K.-H. Protection and restoration of concrete. New Zealand Concrete Construction, No 1, 1988, p. 3-11.

2. KAMAITIS, Z. Repair and strengthening of structures and buildings with synthetic resins. Vilnius: Technika, 1992. 280 p. (in Russian).

3. BENISSON, P. Materials for concrete repair and protection - innovation and performance. Construction Repair, No 6, 1992, p. 27-31.

4. KLEIN, D. H.; JORG, K. Two-component aqueous epoxy binders free of volative organic. Progress in Organic Coatings, 32 (4), 1997, p. 293-297.

5. TYBERG, C. S.; SANKARAPANDIAN, M.; BEARS, K.; SHIH, P.; LOOS, A. C.; DILLARD, D.; McGRATH, J. E.; RIFFLE, J. S.; SORATHIA, U. Tough, void-free, flame retardant phenolic matrix materials. Construction and Building Materials, 13 (6), 1999, p. 343-353.

6. YAROVSKY, I.; EVANS, E. Computer simulation of structure and properties of crosslinked polymers: application to epoxy resins. Polymer, 43 (3), 2002, p. 963-969.
7. REMMELE, T. E. Specifying high-performance coatings for concrete. Construction Specifier, $56(9), 2003$, p. 49-54.

8. CHUNG, D. D. L. Use of polymers for cement-based structural materials. Journal of Material Science, 39 (9), 2004, p. 2973-2978.

9. VIPULANANDAN, C.; LIU, J. Glass-fiber matreinforced epoxy coating for concrete in sulfuric acid environment. Cement and Concrete Research, 32 (2), 2002, p. 205-210.

10. MAYS, G. C. Durability of concrete structures: investigation, repair, protection. London: E\&FN Spon, 1992. $269 \mathrm{p}$.

11. HERRADOR MANUEL, F.; KARBHARI VISTASP, M. Corrosion mitigation - can composite wraps serve as an effective mechanism? In Materials and Processing Technology: Sailing into the Future. Proc of $36^{\text {th }}$ International SAMPE Conference, Covina (USA), 2004, p. 429-443.

12. HERRADOR MANUEL, F.; KARBHARI VISTASP, M. Investigation for corrosion damage in CFRP confined reinforced concrete members. In Materials and Processing Technology: 60 Years of SAMPE Progress. Proc of $49^{\text {th }}$ International SAMPE Symposium, Long Beach (USA), 2004, p. 2981-2994.

13. VAYSBURG, A. M.; EMMONS, P. H. How to make today's repairs durable for tomorrow - corrosion protection in concrete repair. Construction and Building Materials, 14 (4), 2000, p. 189-197.

14. KAMAITIS, Z. Structural design of polymer protective coatings for reinforced concrete structures. Part I: Theoretical considerations. Journal of Civil Engineering and Management, Vol XIII, No 1, 2007, p. 11-17.

\section{GELŽBETONINIŲ KONSTRUKCIJŲ POLIMERINIŲ APSAUGINIŲ DANGŲ PROJEKTAVIMAS. II DALIS. EKSPERIMENTINĖ PATIKRA}

\section{Z. Kamaitis}

S antrauka

Gelžbetoninių konstrukcijų irimas dèl korozijos yra dažnas reiškinys. Konstrukcijos gali būti apsaugotos antikorozinėmis polimerinemis dangomis. Norint efektyviai naudoti įvairias polimerines dangas, reikia nustatyti jų agresyviojoje aplinkoje ribinius būvius ir šių būvių patikrinimo metodiką.

Straipsnyje pateikiami pusiau empiriniai dangoms projektuoti metodai, kurių naudojimas parodytas IKAS dangų, esančių skystojoje cheminejje aplinkoje, pavyzdžiu. Remiantis eksperimentiniais tyrimais ir jų duomenimis, nustatyti dangų irimo mechanizmai ir jų greitis, kurie panaudoti dangu parametrams apskaičiuoti deterministiniais ((5) ir (6) formulès ir 2 lentelè) ir tikimybiniais ((14), (15) ir (16) formulès) metodais. Parodyta įvairių projektavimo parametru jautrumo ịtaka. Svarbus dangoms reikalavimas yra jų atsparumas pleišèjimui ir sukibimas su betono paviršiumi. Pateikta formuojamų dangų traukumo įtempių ir išorès temperatūros pokyčių įtempių, ìvertinant jų relaksacijos procesus, apskaičiavimo metodika ((19), (20), (22) ir (24) formulès).

Pateikti polimerinių dangų tyrimai naudoti IKAS dangoms projektuoti, ịvairių cheminių tirpalų gelžbetoniniams rezervuarams apsaugoti.

Reikšminiai žodžiai: gelžbetoninès konstrukcijos, polimerinès dangos, fizinis (cheminis) atsparumas, difuzija, traukumo ir temperatūriniai įtempiai, patikimumas.

Zenonas KAMAITIS. Dr Habil, Prof Emeritus at the Dept of Bridges and Special Structures. Member of IABSE since 1999. Author and co-author of more than 150 publications, including 6 books. Research interests: concrete structures and bridges, materials, durability, monitoring, and refurbishment. 